\title{
Energy Efficiency of Biogas-Solar Plant
}

\author{
Pavo BALIČEVIĆ ${ }^{*}$, Vedrana BALIČEVIĆ ${ }^{2}$, Aleksandar LIVAZOVIĆ ${ }^{1}$ \\ ${ }^{1}$ Faculty of Agricultue, University of Josip Juraj Strossmayer in Osijek, \\ Kralja Petra Svačića 1d, 31000 Osijek, Croatia \\ ${ }^{2}$ Faculty of Electrical Engineering and Computing, University in Zagreb, \\ Unska 3, 10000 Zagreb, Croatia \\ *Corresponding author: pbalicevic@pfos.hr
}

Bulletin USAMV series Agriculture 72(2)/2015

Print ISSN 1843-5246; Electronic ISSN 1843-5386

DOI 10.15835/buasvmcn-agr: 11443

\begin{abstract}
The consumption of thermal energy for heating the substrate in the process of biogas production represents a significant loss in the total energy balance that can be obtained from the biogas plant and further used as a produced energy. In addition, production process requires considerable additional energy spent for transport and biomass preparation as raw materials for biogas production. Thus, it is very important, among many concepts of biogas energy production, to choose the most convenient one. In practice, the plant for the biogas production is often integrated with a Combined Heat and Power Plant (CHP) for providing energy from biogas into a unique plant. The advantage of such a concept is the possibility of waste heat utilization, inevitably occurring in the drive heat engines, to meet the needs of heat consumption for the substrate heating. However, the energy efficiency of such a process is necessary to compare with the other processes efficiency of biogas energy utilization. For example, the use of solar energy to heat the substrate in conjunction with modern high efficient biogas boiler has been considered as an alternative CHP. Aiming to solve the aforesaid assignment adequate analytical expressions have been derived. A method application has been illustrated on the example of a small farm possessing manure from the pig farm and unused maize stalks residues from agricultural production. Analytical expressions were derived to determine the main biogas plant parameters such as the size and shape of the digester, the plant capacity, biogas yield, generated power strength and others. These features are necessary to determine the heat loss through the digester walls and thermal energy required for heating the substrate. It finally determines the energy utilization of biogas plant with CHP.
\end{abstract}

Keywords: energy efficiency, biogas-solar plant, solar energy.

\section{INTRODUCTION}

Due to the global aspirations of humankind towards the use of renewable and organic energy sources, the main goal of the biogas plants construction, at the moment, is biogas production as a high-quality fuel. The second, but not last goal of a biogas plant building is the disposal of dangerous organic wastes contributing to sustainable waste management. Digestates application as a fertilizer results in recycling and enriching nutrients in organic farming systems.

A biogas plant can be economically justified only if there are high energy efficiency of conversion of primary energy contained in biogas into useful forms of energy. As the biogas production process performing requires consumption of a certain energy in the form of warmth for heating and sanitation substrate; mechanical energy for manipulation and conditioning of raw materials; power for the facility operation and additional energy for the biogas conditioning, it is extremely important to choose the most suitable process among numerous concepts of energy production from biogas in accordance with its consumption. For this purpose it is vital to connect and integrate the biogas production with other activities and adequate energy needs in the local community. These are usually other farms, waste management enterprises, processing industry and other companies. Usually such companies utilize thermal 
energy for space heating, technological processes operation, drying and sanitation, cooling systems drive etc.

Anaerobic digestion, the process by which complex organic matters are decomposed in less complex organic compounds under the influence of various types of anaerobic microorganisms is developed in biogas production plants. Methane, carbon dioxide, ammonia, hydrogen, alcohols and other simple compounds originate in various process phases of the anaerobic digestion. Biogas being a mixture of methane $(55 \div 70 \%)$ and carbon dioxide $(30 \div 35 \%)$ with an addition of hydrogen sulphide $(1 \div 2 \%)$, water vapour $(1 \div 5 \%)$ and oxygen traces, nitrogen, hydrogen and carbon monoxide is obtained at the end of the digestion process (Abbasi et al, 2012). A mixture of two or more different organic substances is used as a raw material or a substrate in most of biogas plants. Anaerobic fermentation of such a mixture is called a co-digestion. It allows stabilizing and optimizing of the digestion process in which biogas is obtained as the main product and digestate as a high quality organic fertilizer - bio fertilizer.

\section{MATERIALS AND METHODS}

\section{Designations of physical, technical and other magnitudes}

$b_{\mathrm{k}}$ - specific biogas yield per mass unit DM from plant mass, $m_{\mathrm{n}}{ }^{3} / \mathrm{kg}_{\mathrm{st}}$;

$b_{\mathrm{S}}$ - specific biogas yield per mass unit DM from manure, $m_{\mathrm{n}}{ }^{3} / \mathrm{kg}_{\mathrm{st}}$;

$c$-specific heat capacity of the complete substrate, $\mathrm{kJ} / \mathrm{kgK}$;

$d_{\mathrm{s}}$ - daily flow of liquid manure per conditional head, $\mathrm{kg} /$ day $\mathrm{CH}$;

$d_{\text {st }}$ - daily flow DM in manure by conditional head, $\mathrm{kg} /$ day $\mathrm{CH}$;

$D_{\text {st }}$ - DM daily flow from the entire herd, $\mathrm{kg} /$ day;

$D_{\mathrm{k}}$ - plant mass daily flow of a certain crop, $\mathrm{kg} /$ day;

$D$ - the total DM daily flow in the substrate, $\mathrm{kg} /$ day;

$\mathrm{H}_{\mathrm{d}}$ - inferior calorific value, $\mathrm{MJ} / \mathrm{m}_{\mathrm{n}}{ }^{3}$;

$j$ - numerousness factor of domestic animal species;

$k$ - increasing factor of bioreactor volume;

$P_{\mathrm{m}}$ - engine power at crankshaft, $\mathrm{kW}$

$Q$ - daily heat capacity of biogas, MJ/day;
$Q_{1}, Q_{2}$ heat losses through the reactor walls, $\mathrm{kW}$;

$Q^{\prime}, Q^{\prime \prime}$ total heat losses of the process heating,

$\mathrm{kW}$;

$Q_{\mathrm{s}}$ - heat to warm up the substrate, $\mathrm{kW}$;

$Q_{0}$ - waste heat of IC engines, $\mathrm{kW}$;

$Q_{\mathrm{p}}$ - heat produced by heat generator, kW;

$Q_{\mathrm{g}}$ - available heat to consumption, $\mathrm{kW}$;

$S$ - the total daily flow of the complete substrate, $\mathrm{kg} /$ day;

$p_{\text {st }}$ - DM mass content in liquid manure, \%;

$V_{\mathrm{S}}$ - daily volume of the liquid manure,, $\mathrm{m}^{3} /$ day;

$V_{\mathrm{sp}}$ - daily volume of the prepared substrate, $\mathrm{m}^{3} /$ day;

$V_{1}, V_{2}$ volume of the first and second reactor, $\mathrm{m}^{3}$;

$V_{\mathrm{B}}$ - average daily biogas yield, $\mathrm{m}_{\mathrm{n}}{ }^{3}$ /day;

$W$ - water quantity in the substrate, $\mathrm{kg} /$ day;

$z$ - number of animal species heads on the farm;

$v$ - species weight factor, $\mathrm{CH} / \mathrm{pc}$;

$r_{\mathrm{s}}$ - liquid manure density, $\mathrm{kg} / \mathrm{m}^{3}$;

$r_{\mathrm{sp}}$ - density of the substrate prepared, $\mathrm{kg} / \mathrm{m}^{3}$;

$x_{C}$ - carbon mass share in DM;

$x_{\mathrm{N}}-$ nitrogen mass share in DM;

$x_{\text {st }}$ - DM mass share in plant mass, $\mathrm{kg}_{\mathrm{st}} / \mathrm{kg}$;

$h$ - efficiency of conversion of thermal energy;

$h_{1}$ - energy efficiency;

$h_{\mathrm{p}}$ - plausible biogas utilization.

\section{Biomass and reactor design properties}

Various reactor operations have been developed aiming to conduct a digestation process taking into account the mode and speed rate of the substrate flow or its retention. The main construction designs of the reactor are as follows:

a) tubular reactor for substrate flow high speed,

b) boiler reactor for lower speeds

c) boiler-batch reactor for single charging.

The main criteria important the reactor design choice are the substrate composition, the kinetics of the substrate degradation and a biocatalyst shape. Flow boiler anaerobic reactor with the substrate mixing was chosen to conduct the analysis in this paper. Such a performance is generally suitable for substrates anaerobic decomposition with lower dry matter content. Charging and discharging of the reactor is conducted by inserting the substrate and digestate exclusion at regular time intervals or continuously by circulation pumps and auger conveyors. Proper digester mixture stirring provides stationary process without mixture density change. 
A single stage anaerobic digestion process in which all the phases of the process (hydrolysis, acidogenesis, acetogenesis and methanogenesis) are conducted in a single reactor is most often applied. The substrate retention time required for the process usually lasts for 20 to 30 days depending on the substrate composition, the process temperature and types of bacteria present. The shortcoming of this reactor design is relatively lower methane yield and more difficult degradation of substances from fresh added substrate for certain bacteria types.

This shortcoming is eliminated by using two reactors connected to the substrate flow instead of a single one. The digestion process takes place in two separated areas which alternately operate. However, it is also a single stage process. Volume of the first area should be large enough to ensure the process stability i.e. the formation of volatile fatty acids in sufficient amount. The most preferred volume ratio between the first and second area is approximately $70 \%: 30 \%$. In this way $80 \%$ of the biogas is produced in the first area. The second area allows methane yield increase by 15 to $18 \%$ compared to the process operation in a single reactor, (Hublin, 2012). The substrate retention in the second area is shorter ,thus, it is often used for inter-storage, wherein continuous and batch charging is combined.
Today, multistage systems of the anaerobic fermentation process have been developed whereby some decomposition phases are spatially separated i.e. conducted in separated reactors. The two-stage systems are characterized by the hydrolysis and acidogenesis processes are conducted in one reactor at a lower $\mathrm{pH}(\mathrm{pH}<6.5)$ whereas methanogenesis is carried out in the second reactor at a higher one $(\mathrm{pH}>7)$ preferred by these processes. The reactors are connected in a loop. Such a system has better work reliability and process stability along with the higher methane productivity. However, the process management is difficult requiring much experience, knowledge and greater investments.

Biogas yield is determined by the organic matter structure especially by the non-degradable substances content and the carbon and nitrogen ratio in the raw material. A suitable ratio of these substances in the substrate can be obtained by mixing organic matters with various shares of the above-mentioned elements. Data on carbon and nitrogen content ratios in organic dry matter (DM) for the different types of plant materials, as well as other data necessary for the design and conduct of biogas production (Burton et al, 2003; Đulbić, 1986) have been provided by Table 1. Analog data on domestic animals manure have been systematically presented in paper Baličević et al. (2014). Raw materials mixing for getting the

Tab. 1. Content of substances and biogas yield in various plant crops

\begin{tabular}{ccccc}
\hline Varieties of arable crops & $\begin{array}{c}\text { DM share in a } \\
\text { plant mass } \\
x_{\mathrm{st}}\left(\mathrm{kg}_{\mathrm{st}} / \mathrm{kg}\right)\end{array}$ & $\begin{array}{c}\text { Nitrogen mass } \\
\text { content in DM } \\
p_{N}(\%)\end{array}$ & $\begin{array}{c}\text { Content ratio } \\
\text { of carbon and } \\
\text { nitrogen in DM } x_{\mathrm{C}} \\
: x_{\mathrm{N}}\end{array}$ & $\begin{array}{c}\text { Biogas yield per DM } \\
\text { mass unit }\end{array}$ \\
\hline Algae & 0.12 & 1.9 & $100: 1$ & $b_{\mathrm{k}}\left(\mathrm{m}_{\mathrm{n}}{ }^{3} / \mathrm{kg}_{\mathrm{st}}\right)$ \\
\hline Mown clover & 0.25 & $1.8,2.8$ & $(17,27): 1$ & $0.42,0.50$ \\
\hline Potatoes processing wastes & 0.075 & 1.5 & $25: 1$ & $0.43,0.52$ \\
\hline Dry maize stalks & 1.0 & 0.8 & $50: 1$ & $0.31,0.54$ \\
\hline Sugar beet leaves & 0.25 & 1.0 & $50: 1$ & $0.38,0.46$ \\
\hline Non-leguminous vegetables & 0.20 & $2.5,4.0$ & $(11,19): 1$ & $0.40,0.50$ \\
\hline Dry saw-dust & 1.0 & 0.1 & $(200,500): 1$ & $0.33,0.36$ \\
\hline Fresh grass & 0.25 & 4.0 & $(12,25): 1$ & $0.28,0.55$ \\
\hline Water lily & 0.22 & $1.5,4.0$ & $(10,20): 1$ & $0.45,0.70$ \\
\hline Dry dead matter & 1.0 & $0.7,1.1$ & $(100,150): 1$ & $0.2,0.3$ \\
\hline
\end{tabular}


substrate can be done regardless of whether they originate from plant crops or domestic animals manure. In the finally prepared substrate organic dry matter should be represented by a mass share of $8 \div 12 \%$.

The substrate for biogas production can be derived from different domestic animals manure. Since different breeds of animals have various weights, a so-called conditional head $(\mathrm{CH})$ was introduced for the purposes of calculating and comparing parameters of biogas production. A conditional head means a set of individuals of an animal species making the total mass of $500 \mathrm{~kg}$. An average number of heads corresponding to the specified weight is determined for a particular species the analysis is conducted for. The reciprocal value of the number is called the factor of the species weight $-n$.

\section{Flow substances balance in the bio- reactor}

The average daily flow of liquid manure

$d_{\mathrm{s}}$ and the appropriate percentage of organic dry matter $p_{\text {st }}$ are given in paper Baličević et al. (2014) for various domestic animals manure. The corresponding daily flow of organic dry matters derived from the manure $d_{\text {st }}$ (reduced to $\mathrm{CH}$ ) and the total daily flow of this matter from the whole herd $D_{\text {st }}$ are as follows:

$$
\begin{aligned}
& d_{\text {st }}=\frac{d_{\mathrm{S}} \cdot p_{\mathrm{st}}}{100} \quad \mathrm{~kg}_{\mathrm{st}} / \text { day CH } \\
& D_{\mathrm{st}}=d_{\mathrm{S}} \cdot \frac{p_{\mathrm{st}}}{100} \cdot z \cdot v \mathrm{~kg}_{\mathrm{st}} / \text { day }
\end{aligned}
$$

The average daily yield of the biogas $V_{\mathrm{B}}$ obtained from manure depends on the animal breed, breed weight factor $n$ and the number of heads $z$ on the farm is as follows:

$$
V_{\mathrm{B}}=b_{\mathrm{S}} \cdot D_{\mathrm{st}} \mathrm{m}_{\mathrm{n}}{ }^{3} / \text { day }
$$

where $b_{\mathrm{S}}$ - specific volume biogas yield (per kilogram of organic dry matter) contained in manure of the certain animal breed.

Daily flow of the liquid manure expressed by the volume is as follows:

$V_{\mathrm{S}}=d_{\mathrm{S}} \cdot z \cdot v / \rho_{\mathrm{S}} \quad \mathrm{m}^{3} /$ day $\mathrm{CH}$
Liquid manure density ranged within the limits $\rho_{s}=1020 \div 1030 \mathrm{~kg} / \mathrm{m}^{3}$.

If plant residues of some arable crops are inserted into a digester with daily plant mass flow $d_{\mathrm{k}}(\mathrm{kg} /$ day), daily biogas yield is calculated by the Table 1 data:

$V_{\mathrm{B}}=D_{\mathrm{k}} \cdot x_{\mathrm{st}} \cdot b_{\mathrm{k}} \quad \mathrm{m}_{\mathrm{n}}^{3} /$ day

Furthermore, an example of the aforementioned expressions application is presented for the individual medium size farm raising $\mathrm{z}=1000$ pigs. By the data mentioned in the paper Baličević et al. (2014) for fattening pigs $d_{\mathrm{S}}=26 \quad v=0,13 \quad p_{\mathrm{st}}=11,54 \% \quad b=0,425 \quad$. The substrate dry matter amount obtained from the manure is calculated by (2):

$D_{\text {st }}=26 \cdot \frac{11,54}{100} \cdot 1000 \cdot 0,13=390 \mathrm{~kg}_{\mathrm{st}} /$ day

(6)

During the substrate preparation the adequate amount of chopped dry cornstalks is added into dissolved manure. A favourable ratio of carbon and nitrogen content in the substrate $x_{C}: x_{N}=(25 \div 35): 1$ should be achieved for good maintenance of methane bacteria during fermentation. Such a ratio is required since methane bacteria consume carbon about 30 times faster than the nitrogen. The substrate ratio $x_{C}: x_{N}=30: 1$ is obtained by adding dry cornstalks amounting $D=D_{\text {st }}+D_{\mathrm{k}}=780 \mathrm{~kg}_{\mathrm{st}} /$ day. Thus, the total daily supply of the substrate dry matter is $D=D_{\text {st }}+D_{\mathrm{k}}=780 \mathrm{~kg}_{\mathrm{st}} /$ day

With a fully complete of the fermentation process the maximum daily amount of biogas produced is determined by the expressions (3)

and (5). Taking into account that $b_{\mathrm{S}}=0,425$ for fattening pigs, $x_{\mathrm{st}}=1, b_{\mathrm{k}}=0,42$ for dry maize is as follows:

$V_{\mathrm{B}}{ }^{\prime}=D_{\mathrm{st}} \cdot b_{\mathrm{S}}+D_{\mathrm{k}} \cdot x_{\mathrm{st}} \cdot b_{\mathrm{k}}=$

$$
=390 \cdot 0,425+390 \cdot 1 \cdot 0,42=330 \mathrm{~m}_{\mathrm{n}}^{3} / \text { day (7) }
$$

Taking into account completed biomass process decomposition by $90 \%$ with the cumulative contribution of the second reactor, the average daily biogas production is as follows:

$V_{\mathrm{B}}=0,9 \cdot 330=300 \mathrm{~m}_{\mathrm{n}}^{3} /$ day

Considering $60 \%$ of methane content in the composition of biogas and its inferior calorific 
value $H_{\mathrm{i}}=35,83 \mathrm{MJ} / \mathrm{m}_{\mathrm{n}}{ }^{3}$ (Labudović, 2000) daily biogas heat capacity is obtained:

$Q=V_{\mathrm{B}} \cdot H_{\mathrm{i}} \cdot 0,6=300 \cdot 35,83 \cdot 0,6=6450 \mathrm{MJ} /$ day (9)

The liquefaction stage should be characterized by dry substance dissolved in the concentrated water $(6,5 \div 12) \%$. The amount of water corresponding to a concentration of $10 \%$ dry matter is $W=D \cdot 90 / 10=7020 \mathrm{~kg}_{\mathrm{w}} /$ day, i.e. the total substrate quantity amounts $S=7800 \mathrm{~kg} /$ day . The substrate daily supply volume, which must be known to determine the bioreactor dimensions including density estimate being $\rho_{\mathrm{sp}}=1050 \mathrm{~kg} / \mathrm{m}^{3}$, is: $V_{\mathrm{sp}}=S / \rho_{\mathrm{sp}}=7,43 \mathrm{~m}^{3} /$ day .

\section{Bioreactor Sizing and Heat Losses Calculation}

The optimal duration of a thermophilic process is 15 to 20 days with a relative biogas yield approximately $60 \%$ of the total biomass capacity, (Samer, 2012). Yield increases with favourable fermentation developing conditions and flow reactors use. The use of two related flow reactors, where single stage process of anaerobic decomposition is conducted, has been considered here. Fifteen days with biogas yield of $90 \%$ was assumed process duration. Such a high degree of decomposition is the result of the process development in the two flow reactors. Regardless the aforesaid conditions, the required volumes of the first and second reactors are as follows:

$V_{1}=k \cdot V_{s p} \cdot n=1,2 \cdot 7,43 \cdot 15=133,74 \mathrm{~m}^{3}$

$V_{2}=V_{1} \cdot 30 / 70=57,32 \mathrm{~m}^{3}$

where $\mathrm{k}$ - factor of bioreactors volume increase for the space above the substrate liquid mass, required for the biogas separation, $k=1,1 \div 1,3$ by Đulbić (1986).

Cylindrical-shaped reactor closed above with a conical roof was selected as a construction and budget example. Ratio of the radius and height of the cylindrical mantle $\mathrm{R} / \mathrm{H}=2$ as well as conical roof height $h=R / 2$ were given. The volume of such a construction type is the same as the hemisphere volume the same radius. Dimensions of the reactor, the radius $\mathrm{R}$ and the height $\mathrm{H}$ of the cylindrical part are as follows:

$$
\begin{gathered}
R_{1}=\sqrt[3]{\frac{3 \cdot V_{1}}{2 \cdot \pi}}=4,0 \mathrm{~m}, R_{2}=3,0 \mathrm{~m}, H_{1}=2,0 \mathrm{~m} \\
, \quad H_{2}=1,5 \mathrm{~m} .
\end{gathered}
$$

The process of the heat losses calculation is shown in the paper Baličević et al. (2013). The surface area of the reactor, heat transfer coefficient and the environment temperature with the external surface side were necessary to determine for the procedure implementation. The heat losses through the digester walls depend on the walls insulation degree and the external atmospheric conditions, particularly environment air temperature and wind speed. As these conditions change significantly during the year, observation was conducted for two annual periods, cooler from October to April with an average surrounding atmosphere temperature of the $6^{\circ} \mathrm{C}$ and warmer from April to October, with an average temperature of $18^{\circ} \mathrm{C}$ in the Vinkovci area (Zrnić, 1978). Mean soil temperatures are $3^{\circ} \mathrm{C}$ and $8^{\circ} \mathrm{C}$ at a $1 \mathrm{~m}$ depth in these periods (Baličević et al, 2013). The substrate temperature in a bioreactor with thermophilic anaerobic digestion process was adopted at 55 ${ }^{\circ} \mathrm{C}$. The calculation was implemented assuming that the reinforced concrete walls of the fermenter cylindrical part $250 \mathrm{~mm}$ thick and reinforced concrete $300 \mathrm{~mm}$ thick floor slab will be built. The conical roof shell was made of $30 \mathrm{~mm}$ thick steel or from artificial materials fixed by steel structure. All the reactor surfaces were coated by the 150 mm thick insulating material protected by an aluminium cover. The coefficients of heat transfer through the reactor walls were calculated, and the obtained values are as follows: for the cylinder wall $\mathrm{k}_{1}=0.25$, conical roof $\mathrm{k}_{2}=0.23$, and the floor panel $\mathrm{k}_{3}=0.17 \mathrm{~W} / \mathrm{m}^{2} \mathrm{~K}$.

The following values of mean daily heat losses via the walls of the first $\left(Q_{1}{ }^{\prime}\right.$ i $\left.Q_{1}^{\prime \prime}\right)$ i.e. the second $\left(Q_{2}^{\prime}{ }^{\prime}\right.$ i $\left.Q_{2}^{\prime \prime}{ }^{\prime}\right)$ reactor in the colder (') and warmer (") year period were obtained by the calculation:

$$
\begin{aligned}
& Q_{1}^{\prime}=1694 \mathrm{~W}, \quad Q_{2}{ }^{\prime}=953 \mathrm{~W}, \\
& Q_{1}{ }^{\prime \prime}=1345 \mathrm{~W}, \quad Q_{2}{ }^{\prime \prime}=756 \mathrm{~W} .
\end{aligned}
$$

The heat required for warming up the substrate prior to insertion into the first reactor should be added to these values: 
$Q_{s}{ }^{\prime}=S \cdot c \cdot \Delta t=7800 \cdot 4,1 \cdot(55-6) / 86400=18,1 \mathrm{~kW}$

,

$Q_{s}^{\prime \prime}=13,7 \mathrm{~kW}$.

Thus the total mean daily thermal energy necessary to be brought into the substrate aiming to maintain the fermentation process in the reactor is for colder i.e. warmer period of the year as follows:

$Q^{\prime}=20,75 \mathrm{~kW}, Q^{\prime \prime}=15,8 \mathrm{~kW}$.

\section{Assessment of the biogas plants utilization degree}

It is obvious that a considerable amount of heat should be conveyed into the process of biogas production by organic matters anaerobic fermentation aiming to maintain the proper temperature for the process development. This heat is often obtained from the CHP that is an integral part of the economy for biogas production where the produced biogas is used as fuel. The CHP plants produce both forms of energy, power and thermal at the same time. By using the rejected thermal energy in internal combustion engines (IC engines), which inevitably occurs as a result of the thermal energy conversion into mechanical work, the energy efficiency of the conversion process increases. This process is justified only if the amount of heat obtained from CHP unit is in accordance with the needs and parameters of thermal energy consumption. If, however, biogas plant environment doesn't have enough requirement for the total produced heat energy consumption in the whole plant operation period, the CHP unit is not economically justified.

Internal combustion engines using biogas as a fuel and producing mechanical energy to drive electric generators are mostly used in the CHP unit of the biogas power-plant (Mitzlaff, 1988). Gas Diesel engines (up to $340 \mathrm{~kW}_{e l}$ ), with a pilot injection with the thermal efficiency reaching values $30 \div 44 \%$ are suitable for smaller biogas plants. Gas Otto engines (from $100 \mathrm{kWel}$ to 1 MWel) with $\eta=34 \div 42 \%$ are suitable for larger plants (Rutz, 2012).

The CHP unit with the appropriate IC engine with $\eta=0,35$ was chosen as an example of biogas production analysis. In this way mechanical energy $P_{m}$ is received on the engine crankshaft and heat
$Q_{0}$ is obtained by removing the engine heat in the amounts:

$$
\begin{aligned}
& P_{m}=\eta \cdot Q=0,35 \cdot 74,65=26,1 \mathrm{~kW}, \\
& Q_{0}=(1-\eta) \cdot Q=48,55 \mathrm{~kW} .
\end{aligned}
$$

The released heat is transferred from the engine in different ways and at different temperatures: by radiation of the engine block $(3 \div 5 \%)$, lubrication $(1 \div 3 \%)$ at $80 \div 90{ }^{\circ} \mathrm{C}$, the engine cooling system $(30 \div 40 \%)$ at $80 \div 90^{\circ} \mathrm{C}$ and exhaust gases $(50 \div 60 \%)$ at $460 \div 550{ }^{\circ} \mathrm{C}$ . Heat dissipation results in approximately $10 \%$ of the heat loss $Q_{0}$. Thus, the usable part is as follows:

$Q_{p}=0,9 \cdot Q_{0}=43,7 \mathrm{~kW}$

After the heat is consumed for the substrate heating, the heat energy remaining for consumers is as follows:

$Q_{g}=Q_{1}-Q_{s}{ }^{\prime}, Q_{g}{ }^{\prime}=23 \mathrm{~kW}, Q_{g}{ }^{\prime \prime}=27,9 \mathrm{~kW}$

If all the remaining heat energy is used by the consumers, energy degree of biogas efficiency from biogas plants with the CHP is:

$$
\eta_{1}=\frac{P_{m}+Q_{g}}{Q}, \quad \eta_{1}{ }^{\prime}=0,66, \quad \eta_{1}{ }^{\prime \prime}=0,72 .
$$

These utilization degrees values are very low compared to other types of fuel combustion in modern boilers, (Recknagel et al, 2012). However, plausible utilization degree is relevant in comparing the utilization of internal biogas energy at the CHP with other ways of getting energy from biogas. It is defined as the total available energy ratio (mechanical and heat energy sum) at the drive heating device exit toward the energy entering the conversion process, (Reynolds, 1965). Since the CHP energy input is equal to the biogas heat capacity, utilization degree is as follows:

$\eta_{p}=\frac{P_{m}+Q_{p}}{Q}=\frac{26,1+43,7}{74,65}=0,935$

The value obtained in utilization degree can be achieved only if the environment requires consumption of the total available heat produced by the CHP unit. However, even then, it is possible only in ideal conditions, ie. when the requirements 
for thermal energy consumption follow its production at their own pace. It almost never corresponds to real situations. The problem is even more pronounced in warmer period, when the heat production is higher and the need for its consumption is usually absent.

On the other hand, biogas represents a very high usable value fuel due to its suitability for transport and storage, the effective implementation possibilities for engine vehicles, the ability of efficient combustion in modern boilers or large thermo-electric power plants and other transformation forms of its internal energy (Weir, 1998). Therefore, for such biogas plants having no sufficient needs to utilize all of the heat energy produced, it is not economically justified to install the CHP unit.

An alternative to the use of the CHP unit aiming to heat the substrate and bioreactor is a combined biogas-solar plant. The system consists of solar collectors and biogas high-efficiency boiler for additional heating during periods of scarcity in solar energy. The heat available for heating purposes was obtained partly from the solar collector and partly from the high efficient

biogas boiler: $Q_{p}=\eta_{k} \cdot Q+Q_{s o l}$. There is no mechanical energy production here, thus, $P_{m}=0$ . By the expression (18) biogas- solar system utilization amounts:

$$
\eta_{p}=\frac{\eta_{k} \cdot Q+Q_{\text {sol }}}{Q+Q_{\text {sol }}}=\frac{\eta_{k}+Q_{\text {sol }} / Q}{1+Q_{\text {sol }} / Q}
$$

Depending on the ratio value $Q_{\text {sol }} / Q$, which

can be between 0 and $¥, \eta_{k} \leq \eta_{p} \leq 1$ is obtained. It is obvious that biogas-solar heating system utilization is much higher than with the use of CHP units.

Heating energy required for warming up the substrate and maintaining the reactor temperature does not require high temperature. Therefore, instead of the CHP unit investments, from the standpoint of energy efficiency directly related to the greenhouse gases emission, low-temperature heat source is more rational to be used. However, to make it economically profitable, it is necessary to harmonize the subsidy system with the need for the total produced heat utilization.

\section{CONCLUSION}

Aiming to determine the energy efficiency of the biogas plant it is necessary to determine heat losses through the bio-fermenter walls and thermal energy required for the substrate heating. The values of all the main parameters of the plant are determined based upon the data on the plant work conditions and the type of available raw materials. Necessity to know all these parameters and a large number of physical and technical properties to determine the real conditions of the process operation makes difficult to conduct the heating budget and a real heat energy loss assessment. Thus, the entire process of calculation, being an integral part of the designed plant, is systematically elaborated and presented in the paper.

Parameters defined in various ways are met in the expert literature entitled as energy efficiency. Here adopted biogas plant energy efficiency shows the share of energy produced by plants per unit of biogas plant heat capacity for other consumers who are beyond the system of biogas production. Budget efficiency is implied in the case of plants that in the Combined Heat and Power unit produces mechanical energy power of $26.1 \mathrm{~kW}$. The plant efficiency is determined during two time periods defined by mean temperatures of the environment atmospheric air. The energy efficiency obtained values for the both monitored periods are very low compared to other types of fuel combustion efficiency in modern boilers.

However, the inverse value of energy efficiency is a direct indicator of the of greenhouse gas emissions amount per unit of the energy produced. The lower the energy efficiency, the higher the $\mathrm{CO} 2$ equivalent emissions are into the atmosphere. Therefore, the argument of the greenhouse gases "zero emissions" in the use of biogas for obtaining energy is meaningless. This effect is even multiplied if the consumption of the heat energy obtained from the Combined Heat and Power unit is not in line with production or even is completely omitted, being not a rare case in practice. It should be added that consumption of highly-valuable energy (exergy) for raw materials transportation and conditioning, being an additional indirect greenhouse gas emissions, has not been taken into consideration in this study.

Another indicator - the plausible utilization was introduced in the paper aiming to compare 
different systems efficiency of biogas internal energy exploitation. The value of this factor shows that the utilization of the CHP units derived using IC engines, contrary to popular belief, is lower than in some other devices.

An alternative way of producing heat energy for warming up the substrate in a biogas plant, using solar collectors complemented by biogas burning in modern gas boilers, provides better efficiency. Derived expression (19) shows that the efficiency of such a plant is higher the higher the share of heat obtained from solar collectors. In this way, the combustion in the boiler consumes only a small part of biogas whereas most of it can be used for energy recovery in other high efficiency systems.

\section{REFERENCES}

1. Abbasi T, Tausef SM, Abbasi SA (2012). Biogas Energy. Springer Science, London.

2. Hublin A (2012). Razvoj procesa i modeliranje anaerobne razgrdnje sirutke. Fakultet kemijskog inženjerstva i tehnologije, Zagreb.

3. Burton $\mathrm{CH}$, Turner C (2003). Manure Managment. Silsoe Research Institut, Bedford, UK.
4. Đulbic M (1986). Biogas, dobijanje, korišćenje i gradnja uređaja. Tehnička knjiga, Beograd.

5. Baličević P, Kralik D, Kraus D, Jovičić D, Mihić Đ (2014). Variables in a model for yield biogas derived from biological substrates. Proceedings of $4^{\text {th }}$ International Conference "Vallis Aurea" focus on regional and innovation development: 31-37, Požega.

6. Labudović B (2000). Ukapljeni naftni plin. Energetika Marketing, Zagreb.

7. Samer M (2012). Biogas plant construction, biogas. InTech, http:www.intechopen.com/ books/biogas-plantconstruction

8. Baličević P, Šumanovac L, Novak I, Mudri A (2013). Construction development of pressure vessels for biogas plant. Proceedings of $48^{\text {th }}$ Croatian and $8^{\text {th }}$ international symposium on agriculture: 712-717

9. Mitzlaff K (1988). Engines for Biogas. GTZ Gmbh, Eschborn.

10. Rutz D (2012). Održivo korištenje toplinske energije iz bioplinskih postrojenja. WIP Renewable Energies, Munchen

11. Recknagel H, Sprenger E, Schramek ER, Čeperković Z (2012). Grejanje i klimatizacija. AGM knjiga, Beograd.

12. Reynolds WC (1965). Thermodinamics. McGraw-Hill Book Company, 1965.

13. Weir T, Twidell J (1998). Renawable energy recources. E\&FN spon, New York.

14. Zrnić SJ (1978). Grijanje i klimatizacija. Naučna knjiga, Beograd. 